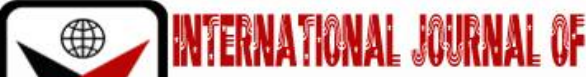

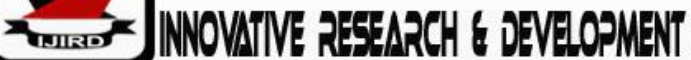

ISSN 2278 - 0211 (Online)

\section{Geo-environmental Hazards Associated with Lead-Zinc Mining in Ishiagu Ebonyi State Nigeria}

Odoabuchi Victor. E
MS.C. Student, Department of Environmental Technology,
Federal University of Technology Owerri, Imo State Nigeria
Nwachukwu M.A
Lecturer, Department of Environmental Technology,
Federal University of Technology Owerri, Imo State Nigeria
Uzoije P.A.
Lecturer, Department of Environmental management,
Federal University of Technology Owerri, Imo state Nigeria

\begin{abstract}
:
Discharge of mine waste to farm lands and consequent drainage to nearby stream cause geo-environmental hazards (Geo-hazards). In this study, geo-hazards due to lead-zinc mining in Ishiagu (Lower Benue Trough Nigeria), were assessed using direct field and laboratory techniques. Field techniques comprised interaction with local farmers, mapping using vertical electric sounding (VES), GPS and photographic tools. Laboratory techniques involved analysis of soil, water and cassava (Manihot esculenta) samples obtained from the mine sites and from the local background (control). Atomic Absorption Spectrophotometer (AAS) was used to measure concentration of heavy metals, while physicochemical parameters were tested using standard procedure. Results show anomalous concentration of Pb, Cd, $\mathrm{Mn}, \mathrm{Zn}, \mathrm{Ca}, \mathrm{K}, \mathrm{Na}, \mathrm{Mg}$, and $\mathrm{pH}$ in the mine site samples against the background. Soil within the mine site have lead pollution index (Pi) of 2.5, downstream Ivo River with lead Pi of 4.0, while cassava had lead Pi of 0.08 indicating toxicity. Downstream Ivo River had $\mathrm{pH}$ enrichment factor of 1.25 indicating high level of acidity. Mine pit depth of $5 \mathrm{~m}$ was estimated against water table depth of $6 \mathrm{~m}$, indicating groundwater vulnerability. Drainage analysis showed about 74 acres of arable land with contaminated topsoil. This land area should be declared brown field, "No Farm Area" for 2-3 years of phytoremediation using local plants.
\end{abstract}

Keywords: Mining, Pb-Zn Ore, Mine water, Drainage analysis, anomaly, Geo-Hazards, Ishiagu

\section{Introduction}

Geo-environmental hazard assessment; a prerequisite to mine design and development is being neglected in some parts of the world, resulting to environmental degradation and food insecurity. Degree of geo-environmental hazards (Geo-hazards) that may be associated with mining activity varies with what is mined, applicable technology, location of mining site and knowledge of the operators. For example, the degree of geo-hazards associated with limestone mining would be less to that of $\mathrm{Pb}-\mathrm{Zn}$ mining. The degree of geo-hazards resulting from mining with advanced environmental friendly technology would not equate with that due to poor technology. Geo-hazard consequences of a mine located in urban vicinity would not equate to that of a mine located in a remote area. Finally, geo-hazard resulting from mining activity operated by well-established company would not equate with that operated by illegal poorly established mining operators.

Geo-hazard associated with $\mathrm{Pb}-\mathrm{Zn}$ mining activity in Ishiagu over the past 40 years is of great concern to environmentalists and the community. Discharge of mine waste to farm lands and consequent drainage to nearby stream is environmental crime that calls for investigation in Ishiagu and in other communities along the Benue Trough of Nigeria. Ishiagu is a semi-urban community with moderate population density located in the lower Benue trough of Nigeria (Figure 1a). Presence of $\mathrm{Pb}-\mathrm{Zn}$ mines and hard rock quarries in the area is responsible to the influx of people from different parts of Nigeria and beyond, making Ishiagu a business vibrant area. Traditionally, Ishiagu people are typically farmers who take advantage of the surface clayey topsoil resulting from weathering of the exposed diabase to excel in the cultivation of tubers such as yam and cassava, and grains, particularly rice. It is possible that Ishiagu community, predominantly the poor farmers are ignorant of the environmental degradation and the obvious health implications. Several Pb-Zn mining companies have operated Ishiagu over the past 40 years, whereas the government office responsible for inspection of mines may not have been forthcoming. The community spokes persons who could have taken up the environmental matter with the operators are probably compromised or incapable. 
Therefore, the aim of this study is to assess the impact of Lead-Zinc mining on soil, cassava (Manihot esculenta) tuber and surface water within Ishiagu mining district Ebonyi State Nigeria.

This goal will be achieved by field and laboratory techniques; Field mapping using GPS, photographs and personal interactions with identified farmers was conducted. The field study was carried out around two lead/zinc mining sites presently in operation in Ishiagu, Ivo Local government area of Ebonyi state Nigeria.

Laboratory and analytical procedure included comparing concentration of selected heavy metals and physico-chemical parameters in soil, surface water and cassava (Manihot esculenta) samples obtained within the drainage area of the discharged mine waste water. This was compared with equivalent background samples (control), collected $1 \mathrm{~km}$ away from the mine site against direction of drainage. Greater emphasis was placed on the measurement and analysis of lead concentration being the target contaminant.

\section{Literature Review}

Lead/Zinc mining and smelting activities are some of the primary sources of heavy metals pollution in the environment (Li et al., 2007). Lead and Zinc mining can result to heavy metal pollution to nearby soil, water and sediment. Some pollutants (Lead, Cadmium, Zinc and Copper) persist in the immediate environment, while others could migrate into distant environmental media (Besser et al., 2007). Specifically, lead inhibits plant growth and the activity of enzymes required for photosynthesis, interferes with cell division and respiration, reduces water absorption and transpiration, and reduces chlorophyll, carotenoid, and adenosine triphosphate (ATP) synthesis (Fargasova, 2001). Lead is a ubiquitous pollutant in the ecosystem. Lead is one of the most widely distributed trace metals. It is ranked second of all hazardous substances by the Agency for Toxic Substances and Disease Registry (ATSDR, 2007). Because of natural deposits and increasing human activities, lead has become ubiquitous in the soil and in the environment. Natural inputs include weathering and erosion of parent rocks that lead to the transfer of large quantities of metals to water bodies and land (Gadd, 2010).

Describing the occurrence of lead-zinc ore in Ishiagu, Oha et al, (2017), stated that the Lower Benue Trough of South-eastern Nigeria, lead-zinc-barium mineralization occurs as widely distributed epigenetic fracture-controlled vein deposits which are restricted to Albian - Turonian sediments. Detailed field studies carried out in Ishiagu, Enyigba-AmekiAmeri, Wanikande-Wanakom, and Gabu-Oshina which together constitute the four main areas of mineralization in the Lower Benue Trough, show that mineralization appears restricted to NW-SE and N-S fractures while the more common NE-SW fractures are barren. Mela et al. (2015) investigated structural orientation of the lead-zinc deposit in Ishiagu and reported that the $\mathrm{Pb}-\mathrm{Zn}$ deposits appear to be in the southern limit of mineralization of the Benue Trough. They continued that the $\mathrm{Pb}-\mathrm{Zn}$ mineralized zone extends over a distance of $500 \mathrm{~km}$ in a narrow belt from Ishiagu in the lower Benue Trough to Zurak in the upper Benue Trough, similar to igneous intrusions in the Trough. Majority of the geologic and topographic features of the area align in the NW-SE direction, and conform to orientation of the folds from the Santonian orogenic episode.

Human activities significantly influence the global cycles of lead. In 2004, 3,150,000 tons of lead were extracted from the earth's crust and brought into circulation in society (USGS, 2006). Lead availability is also affected by the presence of other heavy metals. Orroñoa et al. (2012) reported that lead availability was reduced when it was supplied with five heavy metals ( $\mathrm{Cd}, \mathrm{Zn}, \mathrm{Cr}, \mathrm{Cu}$, and $\mathrm{Ni}$ ) that have an antagonist effect. These authors also reported that, when lead was supplied alone or in ternary combination (with $\mathrm{Zn}$ and $\mathrm{Cu}$ ), its availability increased due to the antagonistic interaction between $\mathrm{Cu}$ and $\mathrm{Zn}$, which made lead more available for plant uptake. The primary effect of lead toxicity in plants is a rapid inhibition of root growth, probably due to the inhibition of cell division in the root tip (Eun et al., 2000). Because health issues associated with lead may occur slowly, environmental lead poisoning could easily be overlooked, but exposure to high levels of lead could cause anemia, weakness, kidney and brain damage (U.S. DHHS, 2007).

\section{Materials and Methods}

\subsection{Area of Study}

Ishiagu is a large clan community of seventeen villages varying in size in terms of land and population. It is one of the largest autonomous communities in Ivo Local Government Area. It is located on the plains of the south- eastern savannah belt in Nigeria (Strafordstones, 2013). The study area (Ishiagu) which lies within latitudes $5^{\circ} 52^{\prime}-6^{\circ} 00^{\prime} \mathrm{N}$ and longitudes $7^{\circ} 30^{\prime}-7^{\circ} 35^{\prime} \mathrm{E}$. It is part of the geologic complex called Benue Trough -a deep linear sediment filled basin which extends from the Niger Delta for over $700 \mathrm{~km}$ towards the northeastern part of Nigeria. It is bounded to the north by Awgu and Aninri areas (Enugu State), to the south by Ugwueke, Isiukwuato (Abia State), to the west by Lokpa and Lekwensi (Abia State) to these east by Akaeze (Ebonyi State). The southeastern railway line runs from Enugu traversing Ishiagu (with both sub-station and main station) down to Port Harcourt. 


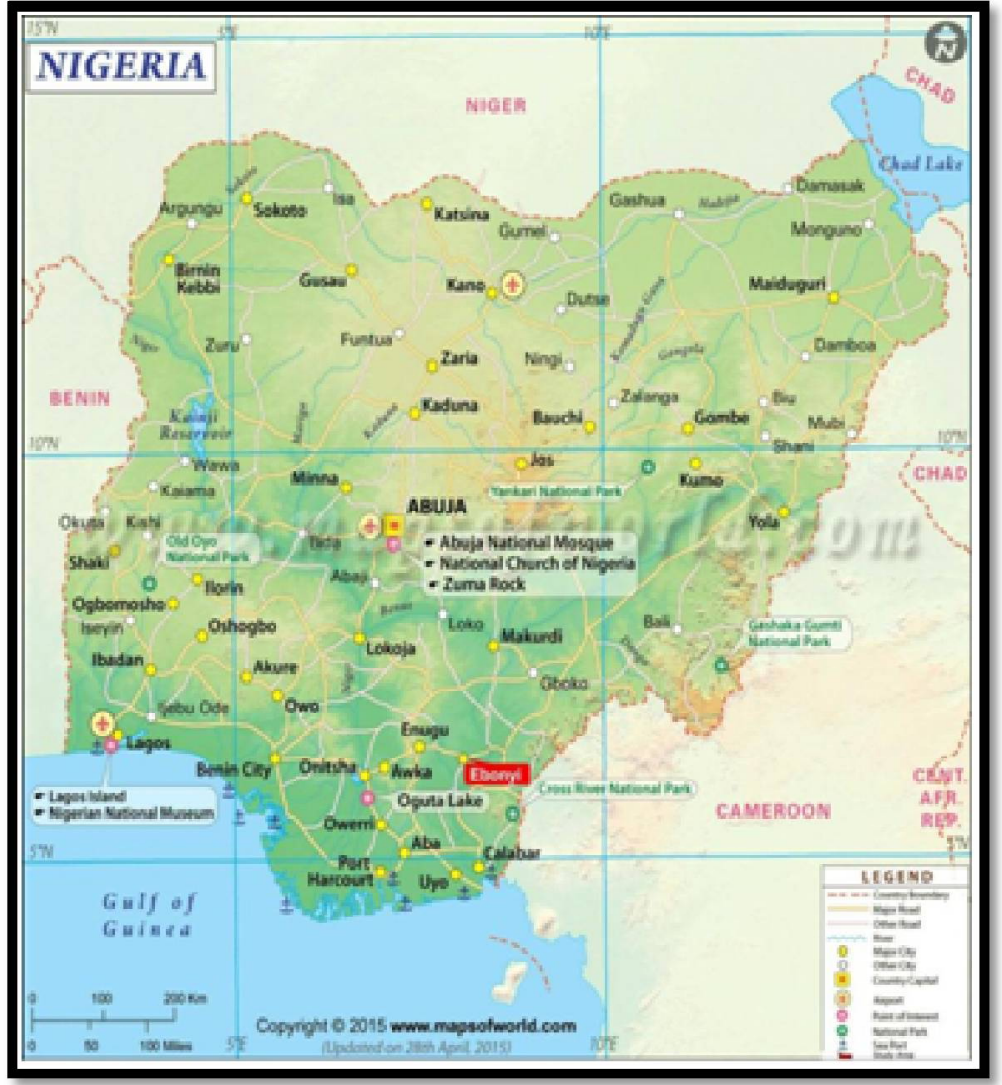

Figure 1: Map of Nigeria Showing Ebonyi State

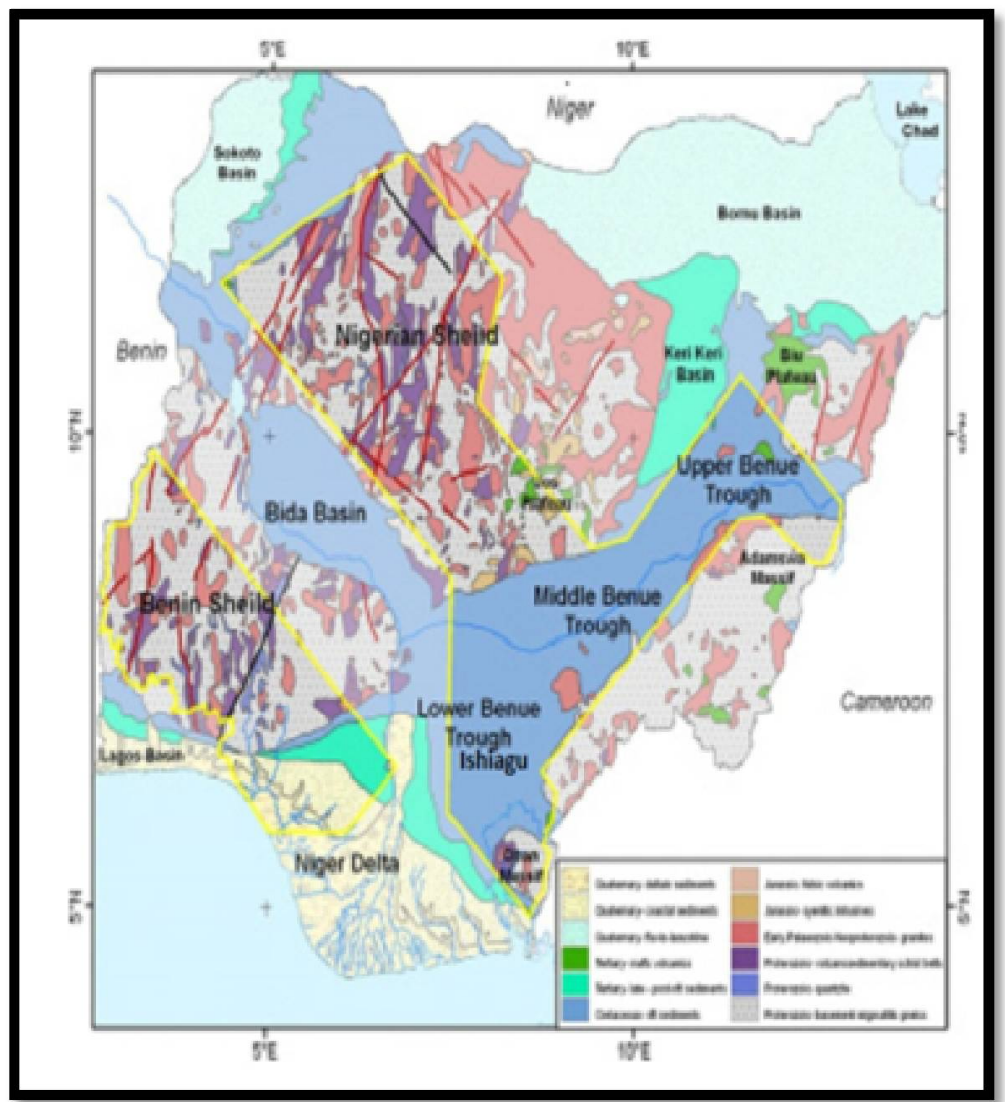

Figure 2: Map showing Ishiagu in the Lower Benue Trough. (modified from Aroh et al., 2007) 


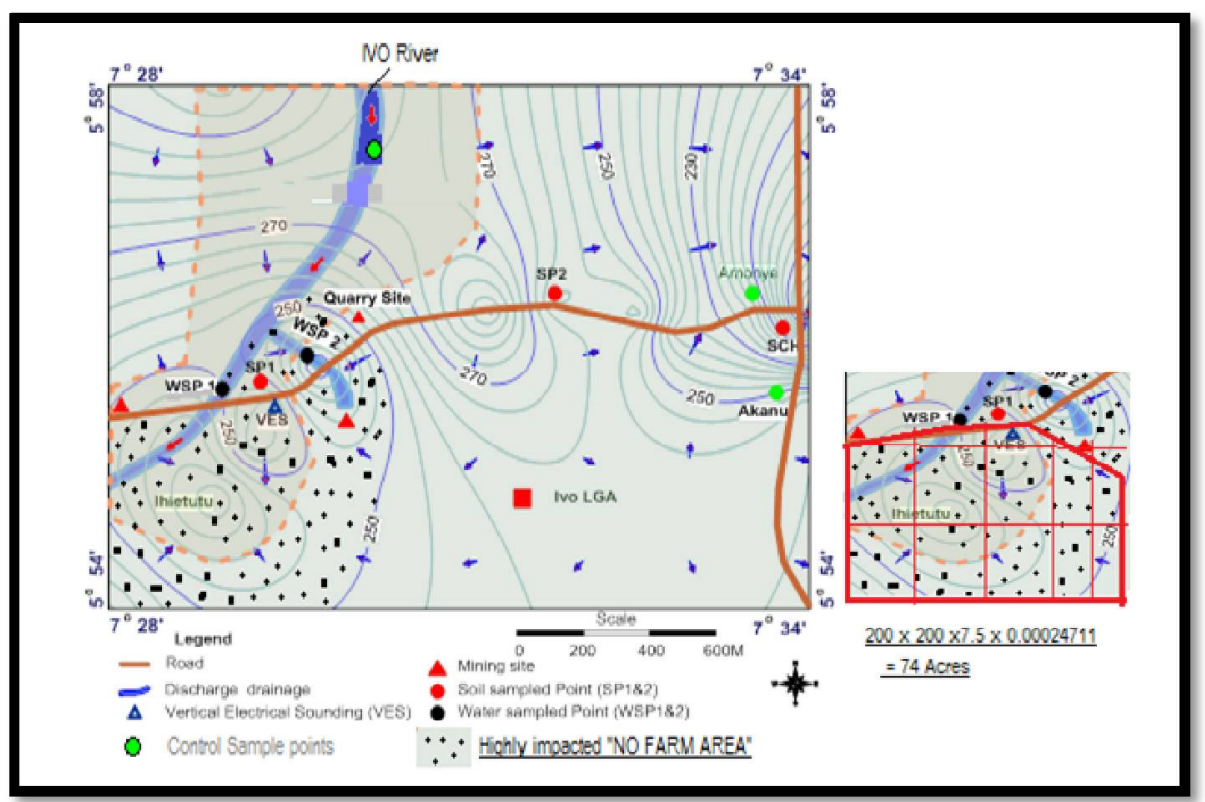

Figure 3: Project Field Map of the Study Area, Showing Topography, Drainage Analysis Sample Collection Points, and the Mine Drainage Impacted Areas at the South-West Corner of the Map, the Impacted Area Also Include the Downstream Segment of the Ivo River

Describing the occurrence of lead-zinc ore in Ishiagu, Oha et al, (2017), stated that the Lower Benue Trough of South-eastern Nigeria, lead-zinc-barium mineralization occurs as widely distributed epigenetic fracture-controlled vein deposits which are restricted to Albian - Turonian sediments. Their field studies carried out in Ishiagu, Enyigba-AmekiAmeri, Wanikande-Wanakom, and Gabu-Oshina which together constitute the four main areas of mineralization in the Lower Benue Trough, show that mineralization appears restricted to NW-SE and N-S fractures while the more common NE-SW fractures are barren. Mela et al. (2015) investigated structural orientation of the lead-zinc deposit in Ishiagu and reported that the $\mathrm{Pb}-\mathrm{Zn}$ deposits appear to be in the southern limit of mineralization of the Benue Trough. They continued that the $\mathrm{Pb}-\mathrm{Zn}$ mineralized zone extends over a distance of $500 \mathrm{~km}$ in a narrow belt from Ishiagu in the lower Benue Trough to Zurak in the upper Benue Trough, similar to igneous intrusions in the Trough (Plate 3.1).

\subsubsection{Tectonic Overview}

The study area, which is part of the Lower Benue Trough, is associated with the separation of the African plate and South American plate and the opening of the south Atlantic during the early Cretaceous. It represents the failed arm of an RRR triple junction and developed as a graben structure. The Benue Trough was subjected to several folding episodes, most notably during the Cenomanian (Nwachukwu, 1972) and the Santonian (Wright, 1976). The Santonian tectonic movement resulted in the folding of sediments in the trough, followed by magmatic activity and Lead/Zinc mineralization (Schlumberger, 1985).The fault traversing sedimentary rocks ranges from major fractures with displacement of several hundred meters to small fractures and micro fractures with only a few meters of displacement (Ofoegbu, 1984; Nwachukwu, 1972).

\subsubsection{Geological Settings}

The Lower Benue Trough is underlain by a thick sedimentary sequence deposited in the Cretaceous period. The geologic formations are: Asu River Group (Albian), Eze - Aku Formation (Turonian), Agwu Shale (Campanian), Nkporo Shale (Santonian), Mamu Formation, Ajali Sandstone and Nsukka Formation (Maastichtian). The Asu River Group is the oldest deposit and comprises of bluish black shales with minor sandstones units. The shales are weathered at the surface. The shales also include limestone intercalations. The sandstone unit of the Eze-Aku Formation is exposed on the northern and southern parts of the Ishiagu area and is generally grayish white (turned brown by weathering), fine grained and poorly sorted. Its strike is ENE-NE with dips of $27^{\circ}-38^{\circ} \mathrm{NW}$ and SE, and rest unconformably on the Albian Asu River Shale. The unit is carbonaceous, bedded, slaggy and fissile on weathering. Both the Albian and Turonian successions in the study areas are folded/refolded into an open symmetrical anticline with the fold axis trending north-east. Each of these lithostratigraphic units is known to surround the igneous rocks (Okeke et al, 1988; Hoque, 1984). The Eze- Aku Shale, the Agwu Shale and the Nkporo Shale overlie the Asu River Group, respectively.

The Eze-Aku Formation has the Amaseri, Makurdi and Itobi Sandstone facies. The Agwu Shale contains Agbani Sandstone facies. The Nkporo Shale includes Afikpo sandstone. The Mamu Formation overlies the Nkporo Shale. The Ajali Sandstone succeeds the Mamu Formation. The Nsukka Formation overlies the Ajali Sandstone. The sedimentary materials were affected by large scale tectonic activities which occurred as a two-phase folding/faulting episode in the pre and post -Turonian times (Nwachukwu, 1972). The tectonism was accompanied by magmatism which resulted in the injection of numerous intrusive bodies into the Eze - Aku and Asu River Group. 


\subsection{Design of the Study}

The work is designed to be conducted through experimental study around two identified lead/zinc mining sites owned by Green field Metal Limited and Coalesce Global Limited respectively, and their waste discharge points at Ishiagu, Ivo Local government area of Ebonyi state.

\subsection{Mapping and Sample Collection Field Techniques}

A compass survey of the area was run. This was to define the limit of investigation and to produce a working base map. The elevations and coordinates of the study area and offset distances of $500 \mathrm{~m}$ were measured using the E-trex GPS and recorded in a ruled sheet. Area of the mining activities investigated was determined through compass survey, and calculations accomplished by triangulation technique.

\subsubsection{Soil Samples}

Field samples of soil and cassava of the study area were undertaken according to standard procedures as well as their controls which were collected $1 \mathrm{~km}$ outside the mining site and against the direction of mine drainage. Top soils $(10 \mathrm{~cm}-20 \mathrm{~cm}$ depth) were collected using auger in labeled polyethene bags and transported to Projects Development Institute (PRODA) Enugu where the soil samples were subsequently dried in an electric oven at 110_C for $12 \mathrm{~h}$. Soil samples collected were carefully kept in a black polythene bag, labeled appropriately and sealed to prevent loss of moisture.

\subsubsection{Cassava Samples}

Cassava samples were also collected from the mining sites and away from the site as control. The cassava samples were subjected to laboratory washing to remove surface dirt, dust and other deposits which may cause contamination.

\subsubsection{Water Samples}

The surface water samples were collected as follows, One sample was collected from the Lead-Zinc mining site and another was obtained $1 \mathrm{~km}$ away from the mining site, labeled and transported to PRODA Enugu for analyses. All samples were collected according to the standard procedure.

\subsection{Analytical Instrumentation}

All chemicals of high purity analytical grade reagents were employed; $\mathrm{HNO}_{3}$ (69\% LR, Breckland Scientific Supplies, U.K) and $\mathrm{HCl}$ (35-38\%, Blulux, Laboratory reagent, U.K) were used for both extraction and acid digestion procedures. Titrisol standard $1000 \mathrm{mg}$ of $\mathrm{Pb}\left(\mathrm{NO}_{3}\right)^{2}$, and $\mathrm{KMnO}_{4}$, (Merck, Germany) dissolved in $1000 \mathrm{~mL}$ distilled water used for preparation of stock standards of $1000 \mathrm{mgL}^{-1}$ and intermediate standard solutions of $100 \mathrm{mg} \mathrm{L}^{-1}$ of Lead, Chromium, Cadmium, Zinc, Copper, Iron and Manganese metals. Distilled water was used throughout the experiment to prepare all the solutions. Digital analytical balance used for all measurements of samples and chemicals. Atomic Absorption Spectrophometer was used to determine the concentrations of Lead, Chromium, Cadmium, Zinc, Iron, Copper and Manganese. A potentiometric digital $\mathrm{pH}$ meter was used to determine the $\mathrm{pH}$ of water samples. Conductivity meter was used to measure the conductivity of water sample solutions.

\subsection{Sample Analysis}

Dried soil samples were ground in a mortar and sieved to below $2.0 \mathrm{~mm}$ mesh sieve size to achieve uniformity of soil particles. About $0.5 \mathrm{~g}$ of the sieved soil were weighed in a crucible and transferred into a muffle furnace and ashed at 550_C for $3 \mathrm{~h}$. The samples were then leached with $65 \mathrm{ml}$ of $1.0 \mathrm{M}$ hydrochloric acid and the leachate analyzed with an Atomic Absorption Spectrophotometer (AAS). Similarly, in pH determination $50 \mathrm{ml}$ deionized water was added to $10 \mathrm{ml}$ dry soil sample, and stirred with a glass rod. Each sample preparation was left to stand overnight and measurement was made with an Orion 920A pH meter with deionized water as the solvent. Cassava (tuber)samples were peeled, ground, and the liquid content extracted and similarly treated like the soil samples.

\subsection{Geophysical Field Techniques}

VES application was necessary for determination of subsurface characteristics including lithologic variation, and depth and thickness of the various layers. The Schlumberger field technique which is known as the vertical electrical sounding was applied. It is also known to be superior over other techniques in distinguishing vertical variation in resistivity, and field operations are faster. The professional assistance of the staff of GEOPROBE International Consultant Limited was employed for the use of their VES equipment (Allied Associate Geophysical Limited, manufacturers Allied Ohmega instrument). AGI 1D automatic analysis inversion software was used for data processing. Inversion resistivity model obtained was constrained to the model curves. VES traverses were run east to west, in the direction of regional strike. Apparent resistivity

$\rho a=K \times R(-\mathrm{m})$

Where $K=$ geometric factor; $R=$ field resistance. Equation (1) can be expressed as follows:

$\rho \alpha=\frac{\pi\left(\frac{\mathrm{AB}}{2}\right) 2-\left(\frac{\mathrm{MN}}{2}\right) 2}{M N} \times \mathrm{R}$

where $\rho a=$ Apparent resistivity (Ohm-m)

$\mathrm{AB}=$ Current electrode spread $(\mathrm{m})$ 
$\mathrm{MN}=$ Potential electrode spread $(\mathrm{m})$

$\mathrm{R}=$ Field resistance $(\mathrm{ohm})$ and

$\pi$ is constant

\subsection{Statistical Analysis}

Statistical analysis is based on the following mathematically relations: equation (1) is pollution index (Pi), Feng et al. (2004).

$\mathrm{Pi}=\frac{C i(M s)}{C i(B)}$ per metal

Where, $\mathrm{Ci}(\mathrm{Ms})$ is concentration of the pollutant in $\mathrm{mg} / \mathrm{l}$ obtained in the mine site and $\mathrm{Ci}(\mathrm{B})=$ Relative background concentration of the pollutant $(\mathrm{mg} / \mathrm{l})$,

Pollution index (Pi) of metal with significant pollution is considered from $\mathrm{Pi}>1$.

Using the formula of the Dutch system (Chee Poh, 2006), the distinction between soil contamination range and soil pollution range as established by contamination/pollution index ( $\mathrm{Ci} / \mathrm{Pi})$, values higher than 1 defines the pollution range and those lower than 1 define the contamination range (equation 2). Pollution range was divided into intervals that define: a slight (1.1- 2.0), moderate (2.1- 4.0), severe (4.1-8.0), very severe (8.1-16.0) and excessive pollution $(>16.0)$, respectively.

The level of acidity $(\mathrm{pH})$ of the Ivo River upstream or the background ( $1 \mathrm{~km}$ off mining site) and downstream from mining site was measured to assess possible impacts of the mining activity using enrichment factor (pHf) equation 3 , Nwachukwu et al. (2017). This is obvious due to reaction of lead-zinc sulphide with mine water to produce acid mine drainage. The acidity released from the sulfide oxidation reactions is of concern because the low-pH solutions increase the solubility of potentially toxic trace metals and semimetals such as $\mathrm{Pb}, \mathrm{Zn}, \mathrm{Cu}, \mathrm{Cd}$, etc., making them more mobile (EMCBC, 2000).

$$
\mathrm{pHf}=\frac{p H(B)}{p H(M s)}
$$

Where $\mathrm{pH}(\mathrm{B})$ is $\mathrm{pH}$ of the background and $\mathrm{pH}(\mathrm{Ms})$ is $\mathrm{pH}$ of the polluted sample.

\section{Results}

\subsection{Field Mapping}

Figure 3 is the project field map combing topography, drainage analysis sample collection points, and the mine drainage impacted areas at the south-west corner of the map. The impacted area also includes the downstream segment of the Ivo River

\subsection{Direct Measurements and Visual Assessments}

The current state of the sample site is indicated by the significant effects of the mine waste on the surface water, farm land and vegetation of the area. The result was taken and recorded as follow

From Plates 4.1 and 4.2 respectively indicated that the surface water was stagnant. Activities of aquatic animals were expected but there was none. The water contained lot of debris. It was observed that both rice and cassava farm lands were vulnerable to the mine drainage. Ivo River is the lead/zinc mine water drainage collection point at Ishiagu. The drainage hose showing in the Figure 6 is a clear evidence of the hazardous act, indicative of unsustainable mining practice. Figure 5 show clearly the destruction of vegetation along the area where the mine waste is emptied. Terrain in this figure indicates dying vegetation as the impact of the mine waste water discharge. Figure 5 also showed cleared portion of land along the drain expected to be cultivated on.



Figure 4: Section of the Ivo River Receiving Mine Drainage 


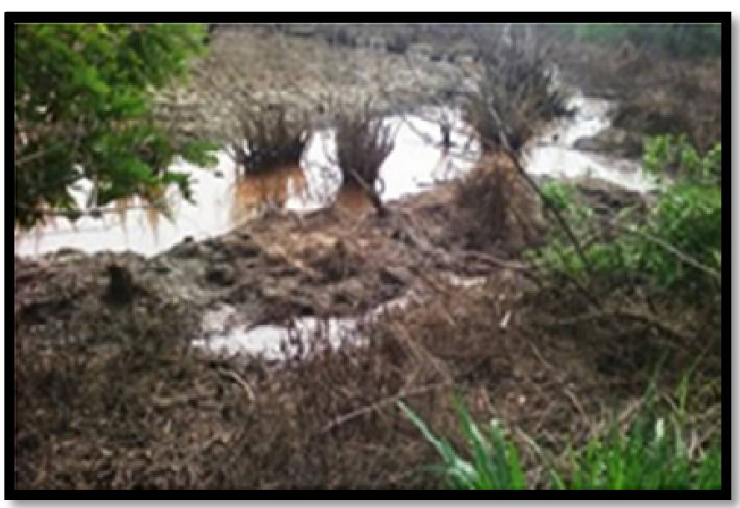

Figure 5: Degraded Farm Land in the Drainage Area of the Discharged Mine Water

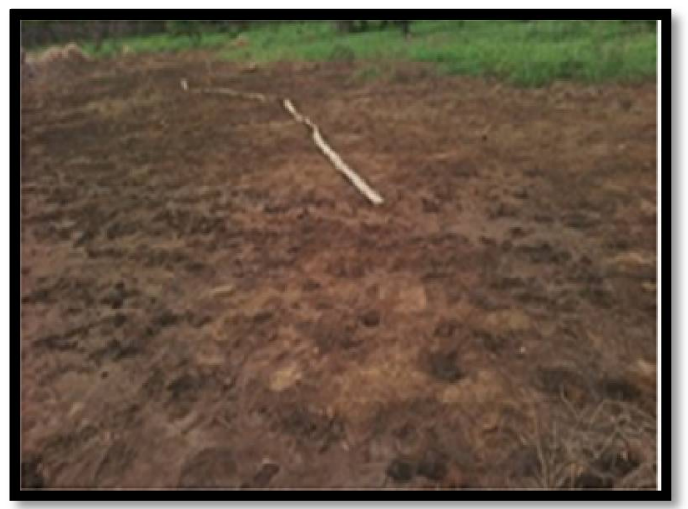

Figure 6: Rice Farm Exposed to the Mine Water Drainage

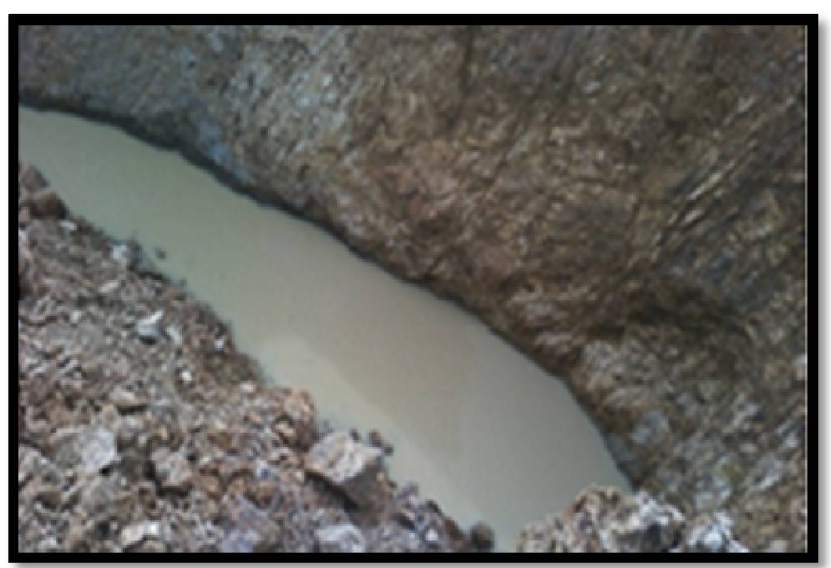

Figure 7: Mine Pit to Depth of 5 M, Against Water Table Depth of $6 \mathrm{M}$

\subsection{Result of Electrical Resistivity Measurement (VES)}

Figure 4. shows the VES curves as constrained to the specified number of geo-electric layers. The various layers are differentiated by color code, with lithology, resistivity values, and thickness properly described. The VES curves are produced using Advanced Geophysics Inc. (AGI) 1D Software. Result show 12 geo-electric layers constrained to 8 layers, indicating shallow water table at depth of $6.2 \mathrm{~m}$, followed by a shallow but economic aquifer to depth of $10 \mathrm{~m}$ (Table 1 ). 


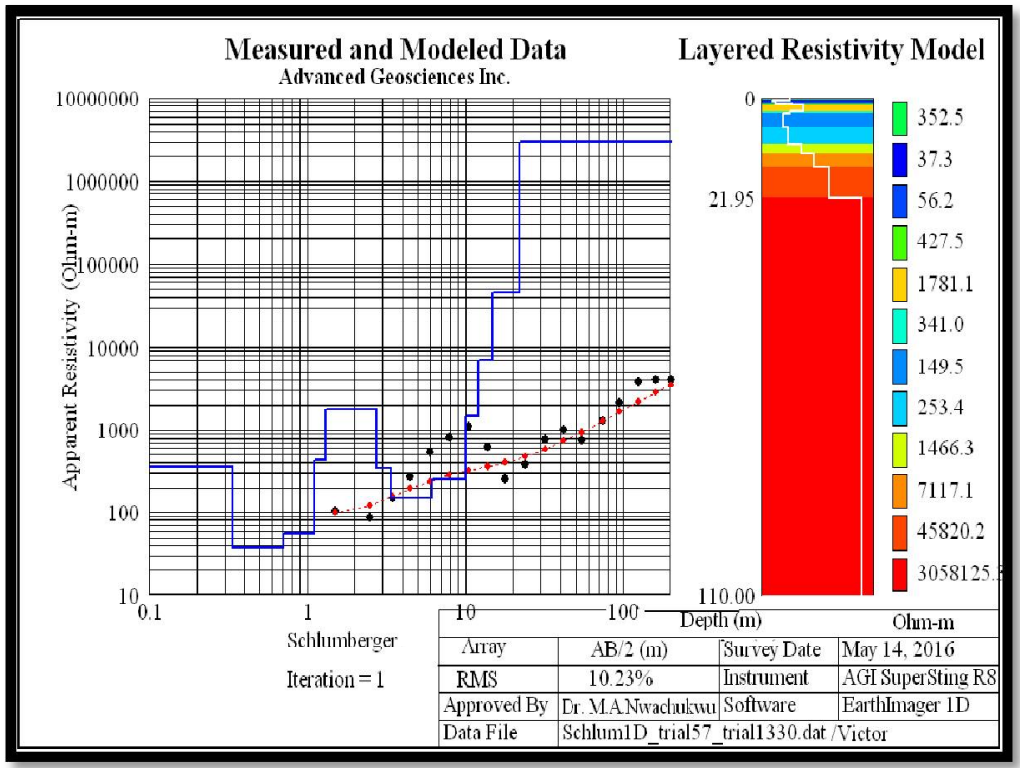

Figure 8: Vertical Electric Sounding Curve

\begin{tabular}{|l|l|l|l|}
\hline Layer\# & \multicolumn{1}{|c|}{ Ohm-m } & \multicolumn{1}{|c|}{ Thickness (m) } & \multicolumn{1}{|c|}{ Bottom Depth (m) } \\
\hline 1 & 37.26 & 0.365 & 0.705 \\
2 & 1781.09 & 1.429 & 2.733 \\
3 & 341.02 & 0.659 & 3.393 \\
4 & 149.53 & 2.797 & $6.189 *$ \\
5 & 253.36 & 3.871 & $10.061^{* *}$ \\
6 & 7117.07 & 2.855 & 14.989 \\
7 & 45820.15 & 6.958 & 21.947 \\
8 & 3058125.33 & \\
\hline
\end{tabular}

\subsection{Result of Soil, Cassava and Surface Water Analyses}

Analytical results presented as Figures (4.2-4.5) of mine site samples indicated clear positive geochemical anomaly compared with the control samples in the following order: Lead; soil $(0.90 \mathrm{ppm})$, cassava $(0.08 \mathrm{ppm})$ and surface water $(0.40 \mathrm{ppm})$ while lead in the control sample soil $(0.35 \mathrm{ppm})$, Cassava $(0.0 \mathrm{ppm})$ and surface water $(0.10 \mathrm{ppm})$. Zn: Mine site soil ( $0.4 \mathrm{mg} / \mathrm{l})$, Control soil $(0.2 \mathrm{mg} / \mathrm{l})$. K: Mine site soil (0.3 mg/l), Control soil $(0.0 \mathrm{mg} / \mathrm{l}) . \mathrm{Pb}, \mathrm{Cd}, \mathrm{Mn}, \mathrm{Zn}, \mathrm{Cr}, \mathrm{Ca}$, $\mathrm{K}, \mathrm{Na}, \mathrm{Mg}, \mathrm{NO}_{3}, \mathrm{PO}_{3}, \mathrm{SO}_{3}$ virtually all parameters measured registered high concentration with the mine site samples, anomalous with the control or the natural background values. This is attributed to the daily discharge of mine water into the adjoining farm lands and consequent drainage into nearby water ways.

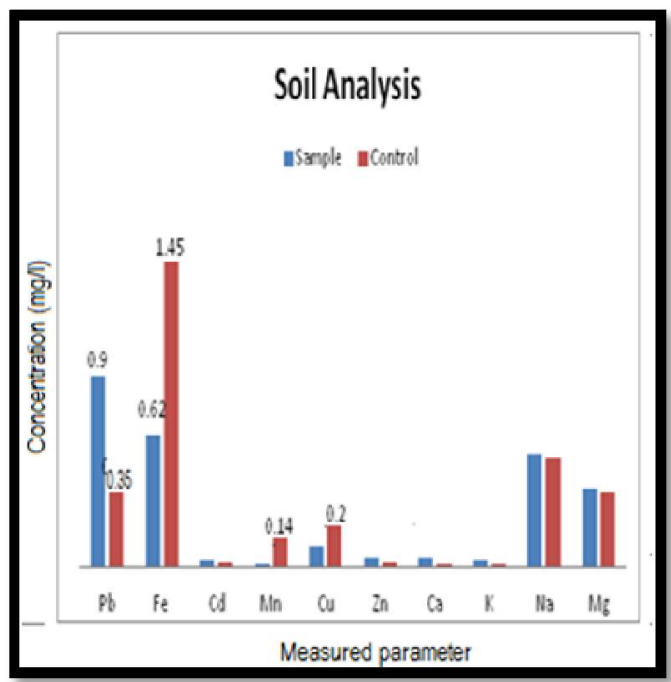

Figure 9: Chart of Soil Analysis 


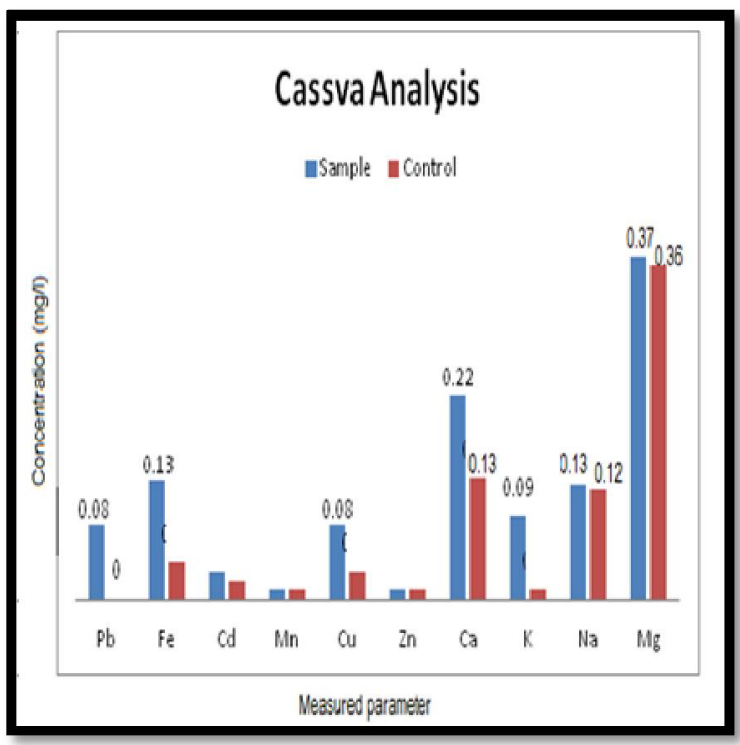

Figure 10: Chart of Cassava Analysis

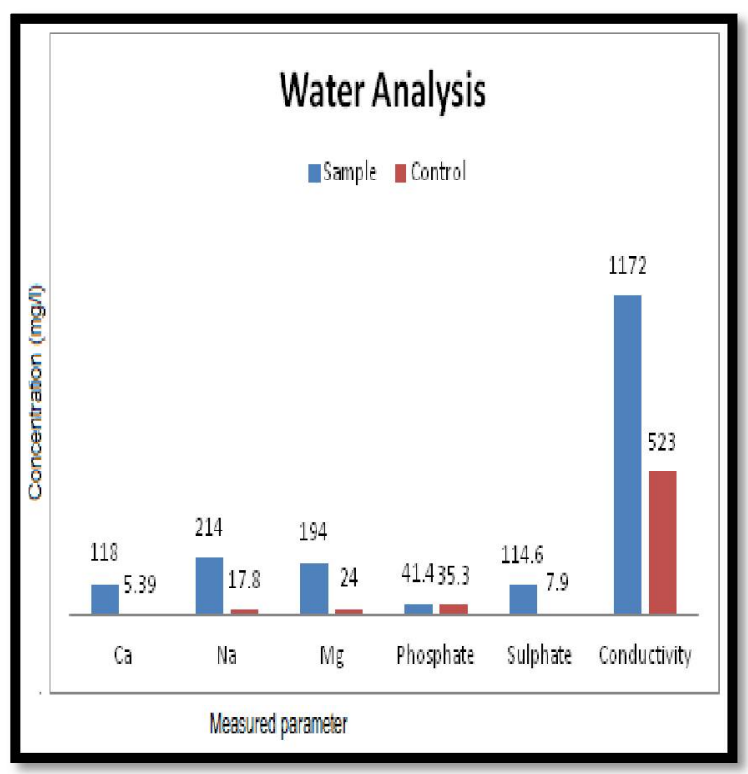

Figure 11: Chart of water Analysis

(Physiochemical Parameters)

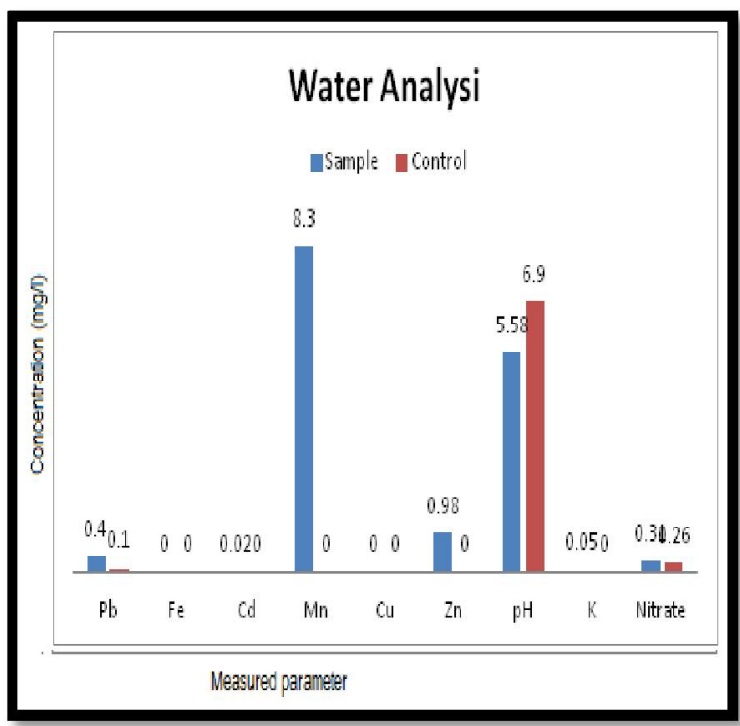

Figure 12: Chart of Water Analysis

(Heavy Metals, Ph, K and Nitrate) 
Further analysis of the laboratory result showed that soil or the farm land area within the mine site is highly polluted with lead, giving a pollution index of 2.5. The Ivo River traversing the mine sites is also highly polluted with lead, giving a pollution index of 4.0. The cassava registered a lead pollution index of 0.08 which indicates contamination. A pH enrichment factor of 1.25 was measured of the Ivo River, indicating a significant level of acidity.

\subsection{Discussion}

Soil as medium for plant growth can serve as a channel for introduction of pollutants such as Lead to the food chain through environmental pollution. Safety of soil from pollution can result to the safety of the food chain and human health. The soil sample showed pollution index of 2.57 and such level of pollution is severe (Chee Poh, 2006). Among other factors, low $\mathrm{pH}$ increases the bioavailability of Lead for plant uptake.

The high presence of lead concentration in soil and cassava samples compared to their control samples is an indication of heavy contamination by lead/zinc mining activities. The presence of $0.08 \mathrm{Mg} / \mathrm{L}$ concentration in the cassava tuber sample, $0.0 \mathrm{Mg} / \mathrm{L}$ in the control and WHO permissible limit of $0.001-0.3 \mathrm{Mg} / \mathrm{L}$ in food crops indicates very severe pollution of food crops with Lead in Ishiagu. Plants readily bioaccumulate large quantity of Lead through their roots without many changes in their total yield and appearance (Musahet et al., 2008; Panket et al., 2011; Otiet et al., 2013). Therefore, the Lead content in the cassava sample is above the WHO permissible limit for food crops. Among heavy metals, lead is a potential pollutant that readily accumulates in soil and sediments. The significant presence of lead in the soil could be caused by the direct discharge of the mine waste water into the open field untreated. From this it is possible for surface water in the area to accumulate relatively high concentration of lead. Lead is very toxic heavy metal even at low concentration which implies that no level of concentration of lead in food or domestic water is acceptable (Tsade, 2016). The pollution index of 2.57 on soil and 0.08 on cassava suggests environmental hazards with obvious health implications. Toxicity of food products now and in future is inevitable except intensive remediation of the soil is commissioned. The presence of $0.08 \mathrm{mg} / \mathrm{l}$ of lead in the cassava sample against $0.0 \mathrm{mg} / \mathrm{l}$ in control cassava sample is another indication that the lead exposure has impacted human objects through the food chain. According to Sharma and Dubey (2005), lead inhibits photosynthesis, upsets mineral nutrition and water balance, changes hormonal status and affects membrane structure and permeability.

Heavy metals are of considerable environmental concern due to their toxicity, non-degradable and cumulative behavior in human tissues (Tong et al., 2010).

Cadmium recorded $0.03 \mathrm{Mg} / \mathrm{L}$ and $0.03 \mathrm{Mg} / \mathrm{L}$ respectively in both soil and cassava samples. Their controls recorded $0.02 \mathrm{Mg} / \mathrm{L}$ and $0.02 \mathrm{Mg} / \mathrm{L}$ respectively while WHO permissible limit is $0.003 \mathrm{Mg} / \mathrm{L}-0.05 \mathrm{Mg} / \mathrm{L}$. Both the soil and cassava samples are polluted with cadmium.

Cadmium is a highly mobile element that can easily be transported through the shoots of plants and uniformly distributed throughout the affected plant (Baker et al., 2000; Sekaraet et al., 2005). When it is exposed to human, it causes diarrhea, severe vomiting, bone fracture, reproductive failure, damage of central nervous system, stomach pains and damage of DNA in addition to cancer development (Otiet et al., 2013 and Ogbonna et al., 2015).

Zinc is an essential element in diet which enhances the essential functioning of the immune system, important for the growth and development of fetus and normal functioning of the brain cells (Otiet et al., 2013). The acceptable limit for human consumption of Zinc is $150 \mathrm{Mg} / \mathrm{kg}$ and the concentration/consumable limit of Zinc on food sample is $5-15 \mathrm{Mg} / \mathrm{kg}$. High concentration of Zinc in human diets is more beneficial than its deficiency as it is detrimental to human health causing stomach cramp, anemia, birth defect, skin irritation and vomiting (Otiet et al., 2013).

Copper, Manganese and Iron occur in association with others and tend to be distributed with Lead and Zinc. Therefore, their association and occurrences enhance bioavailability of Lead for plant uptake.

The Ivo River traversing the mine sites is also highly polluted with lead, giving a pollution index of 4.0 . A $\mathrm{pH}$ enrichment factor of 1.25 was measured of the Ivo River, indicating a significant level of acidity. Also, the concentration of Lead in the study area is $0.40 \mathrm{ppm}$ whereas WHO standard for drinking water and domestic use is $0.01 \mathrm{ppm}$. The aggravated concentration of Lead in surface water of the study area is as a result of channeling the mine tailing into the surface water untreated. However, excessive concentration of Lead in aquatic body tends to bioaccumulate in fish and other aquatic organisms. These aquatic foods can be toxic when consumed by human. Lead is not essential element and does not benefit plant and animal in any way rather, it causes distress to them and diseases burden to humans

Cadmium has the concentration of $0.02 \mathrm{ppm}$ in surface water whereas the WHO standard is $0.003 \mathrm{ppm}$. Several compounds of Cadmium are used in chemical industries and in the manufacture of pesticides, herbicides used in agriculture. Cadmium is extremely toxic to human, and in particular adversely affecting kidneys, and bones. Manganese recorded the concentration of $8.30 \mathrm{ppm}$ in the study area whereas WHO standard is $0.10 \mathrm{ppm}$, Zinc recorded the concentration of $0.98 \mathrm{ppm}$ in the study area whereas WHO standard is $0.30 \mathrm{ppm}$ and Chromium recorded the concentration of $0.16 \mathrm{ppm}$ in the study area whereas the WHO standard is $0.05 \mathrm{ppm}$. Therefore, the concentration of Chromium exceeded the WHO permissible limit. Meanwhile, excessive concentration of Chromium in aquatic body tends to bioaccumulate in fish. The fish can be poisonous to the consumers and can aggravate complications in the human system. The high concentration of lead and presence of zinc, manganese, sulphate, high conductivity and other physicochemical parameters in the surface water sample of the mining site is an indication of surface water pollution and that the surface water of the study area is not safe for use either to feed animals, or for domestic use like fermentation of cassava and drinking. The $\mathrm{pH}$ enrichment factor of 1.25 confirms that the surface water is acidic, resulting to the absence of aquatic life in the immediate downstream segment of the Ivo River. Heavy metals are of considerable environmental concern due to their toxicity, nondegradable and cumulative behaviour in human tissues (Tong et al., 2010). The high conductivity of $1172 \mathrm{uScm}-1$ in the 
sampled surface water of the mine area indicates high turbidity due to suspended colloidal. Turbidity blocks penetration of sunlight and thereby retardation of photosynthesis in aquatic system. The acidic water is also hazardous to aquatic life.

VES result show water table at shallow depth of $10 \mathrm{~m}$, indicating easy reach of contaminants by infiltration, making groundwater in the area vulnerable. Lead is not essential element and does not benefit plant and animal in any way rather, it causes distress to them and diseases burden to humans.

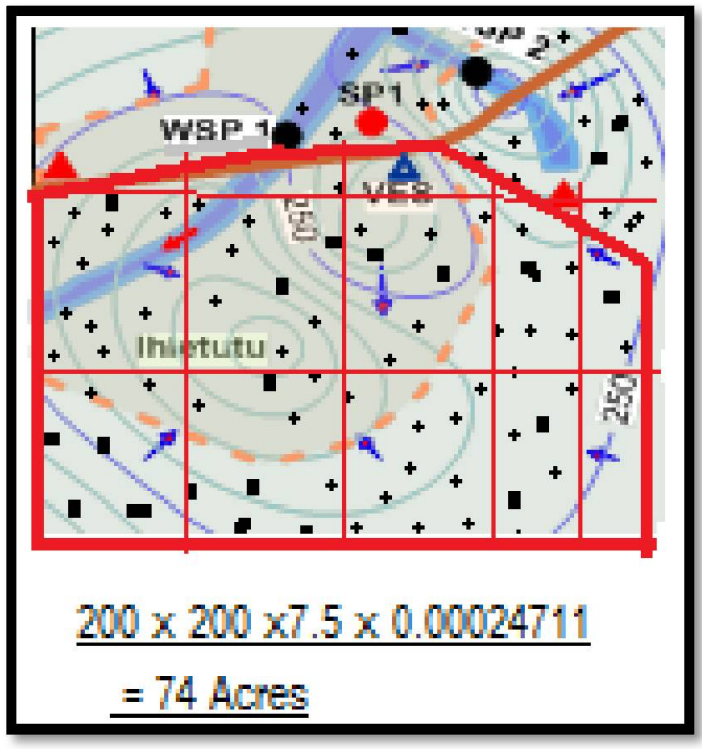

Figure 13: Estimation of Impacted Area

Estimation of the mine drainage impacted areas. The 74 acres of impacted land has been declared "No Farm Area" for 2-3 years of intensive phytoremediation

- The county authority, Ishiagu youths, and the farmers should support and embark on phytoremediation of the "No farm area" using local plants.

\section{Conclusion and Recommendation}

\subsection{Conclusion}

The ecological indicators- cassava root, water, and soil have shown significant impact of lead/zinc mining through both reconnaissance survey and laboratory analysis. The results of the soil, water and cassava samples analyses compare to their control samples showed: presence of lead and other heavy metals in soil, cassava and surface water samples. And presence of lead in plants has shown to inhibit photosynthesis, upsets mineral nutrition and water balance, changes hormonal status and affects membrane structure and permeability. Water sample showed the conductivity of $1172 \mathrm{uScm}{ }^{-1}$ which indicates high turbidity due to suspended colloidal mater in water. Turbidity blocks penetration of sunlight and thereby retardation of photosynthesis in aquatic system. The water is acidic which hider proliferation of aquatic organisms. The water showed $114.60 \mathrm{ppm}$ of sulphate and yet indicated the presence of lead, zinc and other heavy metal like manganese, chromium and so on. Lead is not essential element and does not benefit plant and animal in any way rather, it causes distress to them.

Hence, a plan with the Ivo County authority for environmental awareness seminar in Ishiagu is in the making. The goal of this public seminar is to educate the Ishiagu people particularly the farmers on the hazards of lead exposure, or the dangers of lead contamination of soil and food crops. Possibility of avoiding farming in the lead-zinc impacted areas of Ishiagu, and avoiding the use of the impacted downstream segment of the Ivo River such as fermenting cassava by the river will be explored. How the issue of mine water discharge on arable land could be addressed with the mine operators will be explored. Here is a serious case of food insecurity, as lead enriched farm products cultivated in Ishiagu could reach anywhere in the world through available trade routes.

\subsection{Recommendation}

- Environmental awareness seminar is recommended to Ishiagu community addressing health implications of lead exposure.

- The 74 acres of impacted land should be declared "No Farm Area" for 2-3 years of intensive phytoremediation

- The county authority, Ishiagu youths, and the farmers should support and embark on phytoremediation of the "No farm area" using local plants.

- Mining companies must agree and sign an undertaking to post mining site reclamation, while the host communities ensure compliance to this agreement.

- The mine operators should adhere to acceptable regulatory standard of mining and best waste management practice in disposing their waste, including waste water. 
- Future study should investigate groundwater quality of shallow domestic tube wells used in various homes, and the level of human exposure to lead in Ishiagu.

\subsection{Suggestions for Further Studies}

I suggest that further studies should focus on the following

- The effects of Lead-Zinc mining (mine tailing) on ground water both deep wells and shallow tube wells.

- The environmental impact of Lead-Zinc mining on air quality

- The effects of Lead-Zinc mining on human health and the effectiveness of phytoremediation on Lead-Zinc polluted soil.

\section{References}

i. Aroh KN, Eze CL, Abam TKS, Gobo AE, Ubong IU (2007) Physicochemical properties of pit- water from ishiagu lead/zinc $(\mathrm{Pb} / \mathrm{Zn})$ mine as an index for alkaline classification of the mine drainage. J Appl Sci Environ Manag 11(4):19-24

ii. ATSDR. (2007). Priority List of Hazardous Substances Agency for Toxic Substances and Diseases Registry. Available at:http://www.atsdr.cdc.gov/(accessed 28 July 2009.

iii. Baker, A. J, Megrath, S. P, Reeves, M and Smith, J. A. (2000). Metal accumulator Review of the ecology and physiology of a biological resource for phytoremediation of metal polluted soils.

iv. Besser, J. M., Brumbaugh, W. G., May, T. W., \& Schmitt, C. J. (2007). Biomonitoring of lead, zinc, and cadmium in streams draining lead-mine and non-mining areas, southeast Missouri, USA. Environmental Monitoring and Assessment, 129: 227-241.

v. Chee, Poh, S.; Tahir, N. M.; Zuchi, H. M.; Musa, M. I.; Hork Ng., K.; Noor, A. M., (2006).

vi. Heavy metal content in soil of major towns in the east coast of peninsular Malaysia.

vii. $\quad$ Chinese J. Geoch., 25 (S1), 56.

viii. Environmental Mining Council of BC (EMCBC, 2000). Acid Mine Drainage: Mining and Water Pollution Issues in BC. Report available at: http://www.miningwatch.ca/.

ix. $\quad$ Eun S. O., Youn H. S., Lee Y. (2000). Lead disturbs microtubule organization in the root meristem of Zea mays. Physiol. Plant. 110 357-365

x. Fargasova, A., 2001. Phytotoxic effects of $\mathrm{Cd}, \mathrm{Zn}, \mathrm{Pb}, \mathrm{Cu}$ and Fe on Sinapis alba L.seedlings and their accumulation in roots and shoots. Biology of Plant, 44 (3):471-473.

xi. Feng, H.; Han, X.; Zhang, W.; Yu, L., (2004). A preliminary study of heavy metal contamination in Yangtze River intertidal zone due to urbanization. Mar. Poll. Bull., 49

xii. (1112), 910-915 (6 pages).

xiii. Gadd G. M. (2010). Metals, minerals and microbes: geomicrobiology and bioremediation. Microbiology 156 609643

xiv. Li JY, Jiang AL, Zhang W. 2007a. Salt stress-induced programmed cell death in rice root tip cells. Journal of Integrative Plant Biology 49, 481-486.

xv. Mela, O.V., Onwuemesi A.G., Aniwetalu, E. U. (2015) Exploration of Lead-Zinc (Pb-Zn)

xvi. Mineralization Using Very Low Frequency Electromanetic (VLF-EM) in Ishiagu, Ebonyi

xvii. State. J Geol Geosci 4:214. doi:10.4172/2381-8719.1000214.

xviii. Narayanan, P. (2007). Environmental Pollution Principles, Analysis and Control.First Edition. Satish Kumar Jain pulishers, New Delhi, India.189-191.

xix. Nwachukwu MA, Feng H, Alinnor J (2010). "Assessment of heavy metal pollution in soil and their implications within and around mechanic villages.” Int. J. Environ. Sci. Technol. 7(2):347-358.

xx. Ogbonna, E.C., Out, F.C., Ugbogu, C.O., Nwaugo, O.V., Ugogu, E.A., (2015),

xxi. Public health implications of heavy metal contamination of plants growing in lead-zinc mining area of Ishiagu, Nigeria, Journal of Biodiversity and Environmental Sciences, 17(5): 8-18.

xxii. Oha,1. A, Onuoha, M. K., Dada, S.S. (2017). Contrasting styles of lead-zinc-barium mineralization in the Lower Benue Trough, Southeastern Nigeria; Earth Sci. Res. J. Vol.

xxiii. 21, No. 1 pp. $7-16$.

xxiv. Orroñoa D. I., Schindlera V., Lavadoab R. S. (2012). Heavy metal availability in Pelargonium hortorum rhizosphere: interactions, uptake and plant accum. J. Plant Nutr. 35 1374-1386.

xxv. Oti Wilberforce, J. O. and Nwabue, F. I. (2013). Heavy Metals Effect due to Contamination of Vegetables from Enyigba Lead Mine in Ebonyi State, Nigeria. Environment and Pollution; Vol. 2, No.

xxvi. Sêkara, A., Poniedziaek, M., Ciura, J., \&Jêdrszczyk, E. (2005). Cadmium and

xxvii. Lead Accumulation and Distribution in the Organs of Nine Crops: Implicationsfor Phytoremediation.Polish Journal of Environmental Studies, 14(4), 509-516.

xxviii. Sharma, P. \& Dubey, R. (2005). Lead toxicity in plants. Braz Jl of Plant Physiology. 17:35-52

xxix. Tong, S., Schirnding, Y. E., \& Prapamontol, T. (2000). Environmental lead exposure: A public health problem of global dimensions. Bulletin of the WHO, 78:1068-1077.

xxx. Tsade HK (2016) Atomic Absorption Spectroscopic Determination of Heavy Metal Concentrations in Kulufo River, Arbaminch, Gamo Gofa, Ethiopia.

xxxi. Environ Anal Chem 3:177. doi:10.41722380-2391.1000177. 
xxxii. Usgs. (2006). Mineral Commodity Summaries. U.S. Geological Survey. Available At: Http://Minerals.Usgs.Gov/Minerals/Pubs/Commodity/Lead/Lead_Mcs06.Pdf

xxxiii. U.S. Department Of Health \& Human Services (2007), A Toxicological Profile For Lead pdf 582 pages - Public Health Service Agency for toxic substances and disease registry http.//www.atsdr.cdc.gov/toxprofiles/tp13.pdf

xxxiv. WHO (2009) Mortality and burden of disease attributable to selected major risks. Geneva, http://www.who.int/healthinfo/global_burden_disease/GlobalHealthRisks_report_full.pdf, accessed 20 April 2018). 